\title{
The Influence of Fair Value Measurement on the Pledge of Overconfident Major Shareholders Based on Multiple Regression and Fisher Test
}

\author{
Wei Wang $\mathbb{D}^{1},{ }^{1}$ Xiao-Hui Qu $\mathbb{D}^{2,3}{ }^{2,3}$ Jian-Ju Du $\mathbb{D}^{4},{ }^{4}$ and Jia-Ming Zhu $\mathbb{D}^{5}$ \\ ${ }^{1}$ Institute of Financial and Accounting Studies, Xiamen University, Xiamen 361005, China \\ ${ }^{2}$ Center for Accounting Studies of Xiamen University, Xiamen 361005, China \\ ${ }^{3}$ School of Economics and Management, Harbin Institute of Technology, Shenzhen 518055, China \\ ${ }^{4}$ School of Accounting, Anhui University of Finance and Economics, Bengbu 233030, China \\ ${ }^{5}$ School of Statistics and Applied Mathematics, Anhui University of Finance and Economics, Bengbu 233030, China \\ Correspondence should be addressed to Jia-Ming Zhu; zhujm1973@163.com
}

Received 15 February 2021; Revised 23 February 2021; Accepted 9 March 2021; Published 18 March 2021

Academic Editor: Huihua Chen

Copyright (c) 2021 Wei Wang et al. This is an open access article distributed under the Creative Commons Attribution License, which permits unrestricted use, distribution, and reproduction in any medium, provided the original work is properly cited.

\begin{abstract}
Adopting fair value measurement may bring more earnings fluctuations and induce irrational psychology and radical financing behavior of managers and major shareholders. Based on behavioral corporate governance theory, using the sample of A-share nonfinancial listed companies of China during 2015-2017, this paper empirically examines the regulatory effect of fair value measurement; that is, whether fair value measurement affects the company's financing decisions when major shareholders have irrational psychological characteristics, i.e., overconfidence. The study found that overconfident major shareholders increase the probability of equity pledge and increase the proportion of equity pledge; further inspection found that if the level of accrued earnings management is higher, the adjustment effect of fair value measurement is also higher; when the risk of stock price collapse is higher, fair value measurement obviously increases the probability and ratio of overconfident major shareholders' equity pledge. The above conclusions provide empirical evidence that fair value measurement has a positively regulatory effect on financing decisions of major shareholders.
\end{abstract}

\section{Introduction}

With the development of the market, when people study the issue of corporate governance mechanisms, they find that the behavior of managers more or less shows the characteristics of bounded rationality. Some scholars represented by Langevoort [1] believe that not all human behaviors are completely rational but often irrational. Overconfidence is a kind of irrational psychology. Overconfident major shareholders are usually risk appetite. In order to alleviate financing constraints, they tend to underestimate the risk of control transfer and are more willing to pledge equity than rational major shareholders [2]. The CSMAR database shows that only $12.8 \%$ of Chinese listed companies pledged equity in 2007. Since the China Securities Regulatory Commission issued the "Notice on Matters Concerning Major Shareholders, Directors, Supervisors, and Senior Managers of Listed Companies Increasing Shareholdings of the Company" in 2015, it has further loosened the restrictions on listed companies whose stock prices have fallen by more than $30 \%$ in 10 consecutive trading days as well as the restrictions on the increase in shares of listed companies by shareholders who own $30 \%$ or more of the issued shares. On the day of implementation, the number of major shareholders' holdings increased sharply, reaching $42.1 \%$ by the end of 2017. A high percentage of companies those pledge equity need to consider the corresponding risks. In the actual operation of equity pledge, shareholders need to consider that once the stock market crashes, their control rights may fall. If a company holds financial assets, the gains or losses 
formed by changes in fair value that should be included in the current profits and losses will obviously affect the company's predicted performance and then may affect the company's stock price. For companies with fair value measurement assets, for the purpose of avoiding the risk of control transfer, on the one hand, major shareholders may prefer to use fair value measurement for real earnings management [3] to maintain performance. The existing literature shows that there is room for the management to manipulate the fair value measurement [4]; on the other hand, for overconfident major shareholders, they subjectively tend to ignore the possibility of fair value liabilities, and they hope to reduce the actual control transfer risk by increasing the stock price through fair value changes.

This paper adopts the data of nonfinancial listed companies in Shanghai and Shenzhen stock exchanges in China and takes the companies whose major shareholders increase their holdings and examines whether the moderating effect of fair value measurement will increase the equity pledge behavior of Shareholders. The study found that for companies that use fair value measurement, overconfident major shareholders will increase the probability and ratio of equity pledges. The study found that for companies that use fair value measurement, overconfident major shareholders will increase the probability and ratio of equity pledges. Possible contributions are as follows: (1) expand the application of behavioral corporate governance theory in fair value measurement; (2) it can enrich the relevant literature on the behavioral decision-making of overconfident major shareholders; and (3) provide reference for the financing decisions of companies that use fair value to measure assets.

\section{Theoretical Analysis and Research Hypothesis}

\subsection{Fair Value Measurement and Shareholder Behavior.} The use of fair value accounting will not only affect the accounting behavior of related companies but also affect changes in the financial behavior of companies involved in investment, financing, and dividend distribution. "Accounting Standards for Business Enterprises" (2006) of China has achieved substantial convergence with the International Financial Reporting Standards (IFRS) and comprehensively introduced fair value measurement standards. The use of fair value measurement has brought more fluctuations than historical costs [5]. Fluctuations in the earnings of listed companies are affected by the net gains and losses brought about by changes in fair value, and the information on gains and losses from changes in fair value will also have an impact on the stock prices of listed companies and may also affect the company's decision-making. The option of fair value leaves room for controlling shareholders to manipulate accounting information for the purpose of obtaining control rights. On the one hand, the controlling shareholder can determine the time when financial assets change measurement; on the other hand, it can determine the timing of selling financial assets, which provides space for controlling shareholders to manipulate accounting information $[6,7]$. In other words, the controlling shareholder can use fair value measurement items in order to obtain the private interests of control rights and at the same time realize the manipulation of the company's net assets and net income items.

2.2. Overconfidence of Major Shareholders, Equity Pledge, and Fair Value Measurement. Pledge of Stock Rights, also known as equity pledge, refers to the pledge established by the pledger to obtain loans from banks or other financial institutions with the equity it owns as the pledge object. It is a kind of rights pledge. In recent years, shareholders of listed companies in China have tended to choose equity pledges for financing [8] because equity pledges only require registration and no transfer, which is more convenient than the cumbersome approval procedures for bank loans. The research on equity pledge mainly focuses on three aspects: equity pledge and tunneling behavior, control transfer risk, and equity pledge and earnings management.

\subsubsection{Equity Pledge and Tunneling Behavior. The en-} croachment of major shareholders on the interests of small and medium shareholders is a common drawback in the development of capital markets [9]. The interests of managers and major shareholders are not necessarily consistent; because if the major shareholders occupy the company's funds, it may lead to poor management of the company and decline in performance, which will affect the performance of managers. If the manager's remuneration includes equity incentives, for their own interests, managers will curb the tunneling behavior of major shareholders. Equity incentives reduce the possibility of major shareholders occupying the funds of the listed company when they pledge their equity [10].

\subsubsection{The Risk of Transfer of Control Rights of Equity Pledge.} Although the controlling shareholder's equity pledge eases the financing constraints, in the actual operation of the equity pledge, shareholders need to consider that once the stock market crashes, they may encounter the risk of losing control [11-13]. If the controlling shareholder fails to cover or redeem the stock when the stock price falls to the warning line or the liquidation line, the stock may be sold by the pledgee, leading to the risk of the company's stock price collapse; or the company's stock is forced to liquidate, and the control will be transferred.

2.2.3. Equity Pledge and Earnings Management. When the controlling shareholder pledges equity, due to the information asymmetry between the pledgor and the pledgee, the pledgee is very sensitive to the pledgor's financial information, and the management of the listed company who are forced by the pledgor's supervision will tend to speed up the adjustment of company performance [14], which creates the motivation for earnings management. In order to avoid the transfer of control, listed companies will do their best to maintain stock prices and may also use different earnings management methods to improve performance, such as tax 
avoidance. On the one hand, if agency issues are not considered, tax avoidance can safeguard the company's interests [15], retain part of the company's profits [16], improve the effectiveness of downward real earnings management, and suppress control risks [17]. On the other hand, if the agency problem is considered, the controlling shareholder's tax evasion for the purpose of cashing out [18] will harm the company's interests and increase the risk of control. Another example is that many companies choose to maintain their stock prices in a "high-send transfer" method to avoid the risk of control transfer $[19,20]$. The transfer behavior of Chinese listed companies usually conveys an optimistic attitude, which is "good news." Therefore, "high transfers" is a common method to keep stock prices stable.

In conclusion, the risk of equity pledge, considered as a convenient financing method, mainly comes from the turbulence of the stock market. Listed companies try their best to avoid the transfer of control rights by adopting earnings management, tax avoidance, and "high-end transfer" methods.

Compared with rational major shareholders, under the historical cost model, overconfident major shareholders will also pursue mergers and acquisitions and blind investment, but they have no preference for market fluctuations because historical cost measurement does not reflect fair value fluctuations. However, in fair value measurement, changes in fair value may cause earnings fluctuations, and fair value accounting information has significant explanatory power for stock prices. Profit fluctuations measured by fair value are positively correlated with market fluctuations [21], and the value correlation of fair value measurement is also more relevant [22-24]. Therefore, if an overconfident major shareholder is to reduce the risk of control transfer, whether it is through mergers and acquisitions (goodwill) or investing in financial assets or using fair value measurement for real earnings management, they will be subject to fair value measurement earnings fluctuations. They will be overly optimistic when the market fluctuates downwards and treat unrecognized earnings as part of their profits when the market fluctuates upwards. In addition, from the perspective of earnings management, major shareholders can affect the actual operation of the company. If the company holds assets measured at fair value, the gains and losses from changes in fair value that are included in the net profit will have an impact on the company's performance, affect investors' sentiment, and adversely affect the company's stock price. Overconfident major shareholders are more willing to look forward to the beneficial effects of fair value measurement, believing that the financial assets invested are more likely to receive fair value changes instead of liabilities, thereby reducing the risk of control transfer. Therefore, fair value measurement will also increase the probability of equity pledges by overconfident major shareholders and increase the proportion of equity pledges. To test this question, the following hypothesis is proposed:

H1: under certain other conditions, fair value measurement will increase the probability of overconfident major shareholders to equity pledge and increase the pledge ratio.

\section{Research Design}

\subsection{Variable Definition}

3.1.1. Dependent Variable. The two dependent variables are as follows. Psg is a dummy variable, which indicates whether there was an equity pledge behavior in that year. If the company's shareholders have pledged equity in the current year, it is 1 , otherwise it is 0 . Ratio means equity pledge ratio. The calculation formula of ratio is the number of stocks that still pledged by the major shareholders of the company in that year* $100 /$ total shares of the listed company held by the major shareholders.

3.1.2. Independent Variable. Major shareholders are selected to increase their holdings of the stocks of companies whose return on net assets decreases in the following year as a measure of major shareholders' overconfidence, Con: whether the majority shareholder is overconfident, it is 1 or 0 . Some scholars [25] believe that the majority shareholder's decision to increase shareholding was made under overconfidence because there was no significant difference in the company's performance before and after the majority shareholder increased their shareholding. Therefore, the percentage of the company's shares held by major shareholders is used as a measure of the degree of overconfidence of major shareholders. In addition, this article refers to Cheng Menglan's practice and takes the companies whose major shareholders increase their holdings and the return on net assets of the following year declines sequentially as a sample of major shareholders' overconfidence. Afv means fair value measurement, which is a dummy variable. When the profit and loss from changes in fair value in the income statement are not equal to 0 , it is taken as 1 , and it is taken as 0 in other cases. The fair value items in the income statement will bring a stronger market response [26] and have a higher value correlation because it is included in the net profit $[27,28]$.

3.1.3. Control Variables. According to the research of Wang et al., the control variables are company size ( $L 1$ size): the logarithm of the company's total assets, lagging one period; tangible assets (Ppe): net fixed assets/total assets; CEO duality (Dual): the chairman and general manager are concurrently appointed, $1=$ same person and $2=$ different person; shareholding concentration (Power): the ratio of the largest shareholder's shareholding/the ratio of the second to tenth shareholders' shareholding, and it is mainly used to control the rights of the company's shareholders because the equity pledge may involve the tunneling behavior of major shareholders; asset-liability ratio (Lev): the ratio of total debt to total assets; growth: the growth rate of total assets; and nature of property rights (Soe): if it is a state-owned enterprise, it is 1 ; otherwise, it is 0 .

3.2. Model Design. In order to verify Hypothesis 1, we establish the equity pledge model of this article, referring to Xie's model: 


$$
\begin{aligned}
\text { Psg }= & \alpha_{0}+\beta_{1} \text { Con }+\beta_{2} \text { Afv } \times \text { Con }+\beta_{3} \text { Afv }+\beta_{4} L 1 \text { size } \\
& +\beta_{5} \text { Growth }+\beta_{6} \text { Soe }+\beta_{7} \text { Power }+\beta_{8} \text { Ppe }+\beta_{9} \text { Dual } \\
& +\beta_{10} \text { Lev }+\varepsilon .
\end{aligned}
$$

Because Psg is a dummy variable, the logit model is selected for regression.

$$
\begin{aligned}
\text { Ratio }= & \alpha_{0}+\beta_{1} \text { Con }+\beta_{2} \text { Afv } \times \text { Con }+\beta_{3} \text { Afv }+\beta_{4} L 1 \text { size } \\
& +\beta_{5} \text { Growth }+\beta_{6} \text { Soe }+\beta_{7} \text { Power }+\beta_{8} \text { Ppe } \\
& +\beta_{9} \text { Dual }+\beta_{10} \text { Lev }+\varepsilon .
\end{aligned}
$$

Ratio is the equity pledge ratio. The expected coefficient of the multiplication term is positive, which verifies the positive adjustment effect of fair value measurement.

3.3. Data Source and Sample Selection. Shareholders who held more than 5\% of the shares from 2015 to 2017 are selected as major shareholders. Increased holdings of company shares in the secondary market and a decline in the return on net assets in the following year are used as overconfidence research samples. The data in this article mainly come from the CSMAR database, and the major shareholders' increase in holdings data is all from the Wind database. The nature of the property rights depends on the actual controller, and the data come from the comparison between the CSMAR database and the RESSET database. The industry classification adopts the 2012 industry classification of the China Securities Regulatory Commission. Since the manufacturing industry contains many categories, the manufacturing industry is subdivided. Due to the special financial reporting structure of the financial industry, excluding the financial industry, 21 categories will remain. Among them, (1) exclude listed companies in the financial and insurance industry; (2) exclude ST and * ST companies; and (3) exclude other sample companies with missing data. In order to eliminate the interference of outliers, the main continuous variables are processed by winsorizing up and down 1\%. Finally, 9091 observations were obtained mainly using Stata 15.0 for data processing and regression analysis.

\section{Empirical Test}

4.1. Descriptive Statistics. The data in Table 1 mainly come from the CSMAR database, and the data on the increase in shares held by major shareholders related to the overconfidence (Con) of major shareholders come from the Wind database. The nature of property rights (Soe) depends on the actual controller of the company. The data come from the comparison between the CSMAR database and the RESSET database. Table 1 is descriptive statistics, using Stata 15.0 to calculate the data of A-share nonfinancial listed companies from 2015 to 2017, based on the main variables equity pledge (Psg) and major shareholder overconfidence (Con) to make a balance panel to keep the total number consistent.
TABle 1: Descriptive statistics.

\begin{tabular}{lcccccc}
\hline Variable & $N$ & Mean & sd & min & p50 & $\max$ \\
\hline Psg & 9091 & 0.280 & 0.450 & 0 & 0 & 1 \\
Ratio/100\% & 9091 & 15.120 & 32.590 & 0 & 0 & 577.700 \\
Con & 9091 & 0.200 & 0.400 & 0 & 0 & 1 \\
Afv $\times$ Con & 9091 & 0.140 & 0.350 & 0 & 0 & 1 \\
Afv & 9091 & 0.750 & 0.430 & 0 & 1 & 1 \\
L1 size & 9091 & 22.170 & 1.200 & 19.630 & 22.170 & 26.950 \\
Growth/100\% & 9091 & 0.250 & 0.490 & -0.270 & 0.120 & 3.300 \\
Power/100\% & 9091 & 2.410 & 3.330 & 0.250 & 1.290 & 26.690 \\
Soe & 9091 & 0.320 & 0.470 & 0 & 0 & 1 \\
Ppe/100\% & 9091 & 0.200 & 0.160 & 0 & 0.170 & 0.720 \\
Dual & 9091 & 0.290 & 0.450 & 0 & 0 & 1 \\
Lev/100\% & 9091 & 0.420 & 0.210 & 0.050 & 0.400 & 0.930 \\
\hline
\end{tabular}

In Table 1, the sample of equity pledge has a total of 9091 observations. The number of companies that pledged equity in that year accounted for an average of about $28 \%$ of the total number of companies, and the average equity pledge ratio was about $15 \%$. Overconfidence of major shareholders (Con) accounts for about $20 \%$ of the total, and equity pledge (Psg) is a dummy variable, listed as 0 and 1 . Among the control variables, the minimum value of company growth (growth) is negative $-27 \%$, and the average value is $24 \%$, indicating that although some companies have poor performance, they are still increasing year by year. The average equity concentration (Power) is 2.41, and the largest shareholder's share is usually two to three times the sum of the other two to ten. Very few companies have a gap of 26.69 times. The nature of property rights (Soe) is a dummy variable with an average value of $32 \%$. There are many nonstate-owned enterprises. CEO duality (dual): on average, $29 \%$ of companies have the combination of chairman and general manager. Capital expenditure (Ppe): fixed assets account for an average of $20 \%$ of total assets, and a maximum of $72 \%$ is relatively rare.

4.2. Pearson Coefficient Test. The data in Table 2 are the results of the Pearson correlation coefficient test on the data in Table 1 using Stata 15.0. They are mainly used to observe the correlation between each two variables and whether there is multicollinearity between the main variables.

In the Pearson coefficient test in Table 2, it can be seen that the coefficients of most of the main variables do not exceed 0.5 , and the multicollinearity may be low. The major shareholder equity pledge ratio (Ratio) and major shareholder pledge variable (Psg) are explained variables, and we do not need to care about the correlation between the variables, and the direct coefficient of the crossover term $(\mathrm{Afv} \times \mathrm{Con})$ and major shareholder overconfidence (Con) was 0.818. In order to eliminate the influence of multicollinearity on the regression results, this article did a VIF factor analysis and conditional analysis on the variables. The VIF results are shown on Table 3 , which did not exceed 10, indicating that there is no serious multicollinearity between the variables and will not affect the follow-up inspection. 
TABle 2: Pearson coefficient test.

\begin{tabular}{|c|c|c|c|c|c|c|c|}
\hline Variable & Psg & Ratio & Con & $\mathrm{Afv} \times \mathrm{Con}$ & Afv & L1 size & Growth \\
\hline Psg & 1 & - & - & - & - & - & - \\
\hline Ratio & $0.740^{* * *}$ & 1 & - & - & - & - & - \\
\hline Con & $0.101^{* * *}$ & $0.074^{* * *}$ & 1 & - & - & - & - \\
\hline $\mathrm{Afv} \times \mathrm{Con}$ & $0.096^{* * *}$ & $0.084^{* * *}$ & $0.818^{* * *}$ & 1 & - & - & - \\
\hline Afv & $-0.020^{*}$ & -0.003 & $-0.044^{* * *}$ & $0.235^{* * *}$ & 1 & - & - \\
\hline$L 1$ size & $-0.071^{* * *}$ & $-0.024^{* *}$ & $-0.089^{* * *}$ & $-0.051^{* * *}$ & $0.068^{* * *}$ & 1 & - \\
\hline Growth & $0.096^{* * *}$ & $0.088^{* * *}$ & $0.066^{* * *}$ & $0.051^{* * *}$ & $-0.021^{*}$ & $-0.093^{* * *}$ & 1 \\
\hline Power & $-0.103^{* * *}$ & $-0.088^{* * *}$ & $-0.068^{* * *}$ & $-0.064^{* * *}$ & $-0.034^{* * *}$ & $0.136^{* * *}$ & $-0.106^{* * *}$ \\
\hline Soe & $-0.258^{* * *}$ & $-0.195^{* * *}$ & $-0.124^{* * *}$ & $-0.107^{* * *}$ & $-0.029^{* * *}$ & $0.325^{* * *}$ & $-0.131^{* * *}$ \\
\hline Ppe & $-0.043^{* * *}$ & $-0.046^{* * *}$ & $-0.067^{* * *}$ & $-0.069^{* * *}$ & $-0.066^{* * *}$ & $0.110^{* * *}$ & $-0.180^{* * *}$ \\
\hline Dual & $0.083^{* * *}$ & $0.061^{* * *}$ & $0.036^{* * *}$ & $0.025^{* *}$ & 0.015 & $-0.139^{* * *}$ & $0.067^{* * *}$ \\
\hline Lev & $-0.032^{* * *}$ & $0.023^{* *}$ & $-0.020^{*}$ & 0.001 & $0.032^{* * *}$ & $0.197^{* * *}$ & 0.001 \\
\hline Variable & Power & Soe & Ppe & Dual & Lev & - & - \\
\hline Power & 1 & - & - & - & - & - & - \\
\hline Soe & $0.252^{* * *}$ & 1 & - & - & - & - & - \\
\hline Ppe & $0.112^{* * *}$ & $0.198^{* * *}$ & 1 & - & - & - & - \\
\hline Dual & $-0.099^{* * *}$ & $-0.255^{* * *}$ & $-0.064^{* * *}$ & 1 & - & - & - \\
\hline Lev & $0.121^{* * *}$ & $0.316^{* * *}$ & $0.029^{* * *}$ & $-0.136^{* * *}$ & 1 & - & - \\
\hline
\end{tabular}

Note. ${ }^{* * *},{ }^{* *}$, and ${ }^{*}$ represent significance levels of $1 \%, 5 \%$, and $10 \%$, respectively.

TABLE 3: Variance inflation factor (VIF) test.

\begin{tabular}{|c|c|c|c|c|c|c|c|c|c|c|c|}
\hline VIF test & Explanatory variable & Con & $\mathrm{Afv} \times \mathrm{Con}$ & Afv & L1 size & Growth & Power & Soe & Ppe & Dual & Lev \\
\hline \multirow{2}{*}{ Explained variable } & Psg & 3.700 & 3.970 & 2.640 & 1.160 & 1.080 & 1.110 & 1.400 & 1.540 & 1.080 & 1.330 \\
\hline & Ratio & 4.180 & 4.650 & 2.500 & 1.120 & 1.100 & 1.040 & 1.160 & 1.470 & 1.060 & 1.270 \\
\hline
\end{tabular}

Note. The values in Table 3 are the results of VIF inspection.

4.3. Regression Results of Fair Value Measurement, Overconfidence of Major Shareholders, and Equity Pledge. In the multiple regression process in Table 4 , industry and annual variables were controlled, and the results proved Hypothesis 1. Columns (1) and (2) are the regression results of model equity pledge (Psg) and model pledge ratio (Ratio), respectively. The multiplication item (Afv $\times$ Con) in column (1) represents the influence of fair value measurement on the overconfidence of major shareholders. The regression result is significantly positive at the $1 \%$ level, indicating that the adjustment effect of fair value measurement will increase the probability of Equity Mortgage behavior of overconfident major shareholders. The coefficient of the crossover term $(\mathrm{Afv} \times \mathrm{Con})$ between the fair value measurement and the manager's overconfidence in column (2) is significantly positive at the $1 \%$ level. This fully verified Hypothesis 1 shows that fair value measurement will greatly increase the probability of overconfident major shareholders' equity pledge and increase the proportion of equity pledge.

\section{Further Research}

5.1. The Influence of Earnings Management on the Adjustment of Fair Value Measurement. Earnings management is an unavoidable topic in corporate governance. When major shareholders are financing, they need to manipulate earnings to adjust their financial status. It needs to be tested whether it will affect the adjustment of fair value measurement. We measure the model of accrued earnings management of a company by referring to the previous literature $[29,30]$.

$$
\frac{\mathrm{TA}_{i t}}{A_{i t-1}}=\alpha_{i}\left[\frac{1}{A_{i t-1}}\right]+\beta_{1 i}\left[\frac{\Delta \mathrm{REV}_{i t}}{A_{i t-1}}-\frac{\Delta \mathrm{REC}_{i t}}{A_{i t-1}}\right]+\beta_{2 i}\left[\frac{\mathrm{FA}_{i t}}{A_{i t-1}}\right]+\beta_{3 i}\left[\frac{\mathrm{IA}_{i t}}{A_{i t-1}}\right]+\varepsilon_{i t},
$$

where $\mathrm{TA}_{\mathrm{it}}$ is equal to total accrued profits of company $i$ in year $t ; A_{i t-1}$ is equal to total assets of company $i$ in year $t-1$; $\mathrm{TA}_{i t-1}$ is equal to total accrued profits of company $i$ in year $t-1 ; \Delta \mathrm{REV}_{i t}$ is equal to $i$, the amount of changes in the company's operating income in year $t$; $\mathrm{REC}_{i t}$ is equal to the increase in receivables of company $i$ in year $t ; \mathrm{FA}_{\mathrm{it}}$ is the fixed assets of company $i$ in year $t$; and IA $_{i t}$ is equal to the intangible assets and other long-term assets of company $i$ in year $t$.
$\mathrm{MJ}=1$ means higher than the average earnings management degree which is greater than the mean value of $\mathrm{TA}_{i t} /$ $A_{i t-1}$, and $\mathrm{MJ}=0$ means the reverse. Descriptive statistics are in Table 5, and the results are shown in Table 6. The coefficients of Afv $\times$ Con in columns (1) and (2) are -0.0618 and 0.617 , respectively, and the latter is significantly positive at the $1 \%$ level. The empirical $P$ value between groups is 0.073 which means significant. It shows that in companies 
TABLE 4: Multiple regression of fair value measurement, overconfidence of major shareholders, equity pledge, and pledge ratio.

\begin{tabular}{lcccc}
\hline Regression model & \multicolumn{2}{c}{ (1) Psg } & \multicolumn{2}{c}{ (2) Ratio } \\
\hline Con & -0.065 & $(0.558)$ & $-3.042^{*}$ & $(0.062)$ \\
Afv $\times$ Con & $0.247^{* * *}$ & $(0.005)$ & $5.914^{* * *}$ & $(0.003)$ \\
Afv & -0.032 & $(0.783)$ & $-3.046^{*}$ & $(0.052)$ \\
L1 size & -0.017 & $(0.459)$ & 0.326 & $(0.293)$ \\
Growth & $0.229^{* * *}$ & $(\leq 0.001)$ & $3.246^{* * *}$ & $(0.001)$ \\
Power & $-0.056^{* *}$ & $(0.039)$ & $-0.507^{* * *}$ & $(\leq 0.001)$ \\
Soe & $-1.670^{* * *}$ & $(\leq 0.001)$ & $-17.090^{* * *}$ & $(\leq 0.001)$ \\
Ppe & 0.315 & $(0.134)$ & -0.605 & $(0.842)$ \\
Dual & $0.203^{* * *}$ & $(0.001)$ & $2.657^{* *}$ & $(0.011)$ \\
Lev & $0.822^{* * *}(\leq 0.001)$ & $15.670^{* * *}$ & $(\leq 0.001)$ \\
\hline Year/Ind & \multicolumn{3}{c}{ Yes } & \multicolumn{2}{c}{ Yes } \\
$N$ & \multicolumn{2}{c}{5852} & \multicolumn{3}{c}{5869} \\
Adj. $R^{2}$ & \multicolumn{2}{c}{0.110} & 080 \\
\hline
\end{tabular}

Note. $^{* * *},{ }^{* *}$, and ${ }^{*}$ represent significance levels of $1 \%, 5 \%$, and $10 \%$, respectively. $P$ value is represented in brackets.

Table 5: Descriptive statistics of MJ.

\begin{tabular}{lccccc}
\hline Variable & Mean & sd & min & p50 & $\max$ \\
\hline MJ & 0.780 & 0.410 & 0 & 1 & 1 \\
\hline
\end{tabular}

TABLE 6: The influence of earnings management on the adjustment of fair value measurement.

\begin{tabular}{|c|c|c|c|c|}
\hline $\begin{array}{l}\text { Regression } \\
\text { model } \\
\text { Earnings } \\
\text { management }\end{array}$ & $\begin{array}{c}(1) \\
\text { Psg } \\
M J=0\end{array}$ & $\begin{array}{c}(2) \\
\text { Psg } \\
M J=1\end{array}$ & $\begin{array}{c}(3) \\
\text { Ratio } \\
\mathrm{MJ}=0\end{array}$ & $\begin{array}{c}(4) \\
\text { Ratio } \\
\mathrm{MJ}=1\end{array}$ \\
\hline Con & $\begin{array}{c}0.188 \\
(0.270)\end{array}$ & $\begin{array}{l}-0.312^{*} \\
(0.074)\end{array}$ & $\begin{array}{l}-2.855 \\
(0.193)\end{array}$ & $\begin{array}{l}-3.313 \\
(0.175)\end{array}$ \\
\hline $\mathrm{Afv} \times \mathrm{Con}$ & $\begin{array}{l}-0.062 \\
(0.814)\end{array}$ & $\begin{array}{c}0.617^{* * *} \\
(0.001)\end{array}$ & $\begin{array}{l}6.465^{*} \\
(0.068)\end{array}$ & $\begin{array}{c}7.251^{* * * *} \\
(0.008)\end{array}$ \\
\hline $\mathrm{Afv}$ & $\begin{array}{l}-0.038 \\
(0.824)\end{array}$ & $\begin{array}{l}-0.066 \\
(0.659)\end{array}$ & $\begin{array}{l}-3.344 \\
(0.130)\end{array}$ & $\begin{array}{l}-2.428 \\
(0.261)\end{array}$ \\
\hline$L 1$ size & $\begin{array}{c}0.027 \\
(0.592)\end{array}$ & $\begin{array}{l}-0.014 \\
(0.605)\end{array}$ & $\begin{array}{c}0.476 \\
(0.409)\end{array}$ & $\begin{array}{l}0.586^{*} \\
(0.082)\end{array}$ \\
\hline Dual & $\begin{array}{l}0.454^{* * *} \\
(\leq 0.001)\end{array}$ & $\begin{array}{c}0.201^{* * *} \\
(0.001)\end{array}$ & $\begin{array}{l}4.256^{* *} \\
(0.030)\end{array}$ & $\begin{array}{c}3.385^{* * *} \\
(0.001)\end{array}$ \\
\hline Prof & $\begin{array}{c}-0.090^{* * *} \\
(0.002)\end{array}$ & $\begin{array}{c}-0.046^{* * *} \\
(0.002)\end{array}$ & $\begin{array}{c}-0.550^{* * *} \\
(\leq 0.001)\end{array}$ & $\begin{array}{c}-0.523^{* * *} \\
(\leq 0.001)\end{array}$ \\
\hline Growth & $\begin{array}{c}-1.802^{* * *} \\
(\leq 0.001)\end{array}$ & $\begin{array}{c}-1.515^{* * *} \\
(\leq 0.001)\end{array}$ & $\begin{array}{c}-18.460^{* * * *} \\
(\leq 0.001)\end{array}$ & $\begin{array}{c}-16.020^{* * *} \\
(\leq 0.001)\end{array}$ \\
\hline Ppe & $\begin{array}{c}0.569 \\
(0.223)\end{array}$ & $\begin{array}{c}0.395 \\
(0.120)\end{array}$ & $\begin{array}{c}0.597 \\
(0.903)\end{array}$ & $\begin{array}{c}4.102 \\
(0.248)\end{array}$ \\
\hline Dual & $\begin{array}{c}0.039 \\
(0.768)\end{array}$ & $\begin{array}{c}0.208^{* * *} \\
(0.003)\end{array}$ & $\begin{array}{c}1.737 \\
(0.406)\end{array}$ & $\begin{array}{l}2.608^{* *} \\
(0.020)\end{array}$ \\
\hline Lev & $\begin{array}{c}0.083 \\
(0.808) \\
\end{array}$ & $\begin{array}{l}0.918^{* * *} \\
(\leq 0.001)\end{array}$ & $\begin{array}{c}7.127 \\
(0.115) \\
\end{array}$ & $\begin{array}{c}15.840^{* * *} \\
(\leq 0.001)\end{array}$ \\
\hline Year/Ind & Yes & Yes & Yes & Yes \\
\hline $\begin{array}{l}\text { Empirical } P \\
\text { value }\end{array}$ & \multicolumn{2}{|c|}{0.073} & \multicolumn{2}{|c|}{0.481} \\
\hline$N$ & 1634 & 5088 & 1637 & 5106 \\
\hline Adj. $R^{2}$ & 0.141 & 0.097 & 0.100 & 0.064 \\
\hline
\end{tabular}

Note. ${ }^{* * *},{ }^{* *}$, and ${ }^{*}$ represent significance levels of $1 \%, 5 \%$, and $10 \%$, respectively. The empirical $P$ value is the result of 1000 repeated sampling of the Fisher combination test. When $P<0.1$, the difference between groups is significant, and empirical $P$ value represents the significance of the cross product; the same is given as follows. with a higher level of earnings management, the adjustment effect of fair value measurement is more significant, which obviously increases the probability of overconfident major shareholders to pledge equity. In columns (3) to (4), the coefficients of the cross-multiplication term Afv $\times$ Con are significantly positive at the levels of $10 \%$ and $1 \%$, respectively, but the empirical $P$ value between groups is not significant. This shows that regardless of the level of earnings management, fair value measurement can easily affect overconfident major shareholders, resulting in a greater proportion of equity pledges.

Accrued earnings management is positively related to the moderating effect of fair value measurement. This may be due to the high opacity of company information when accrued earnings management occurs, and it is more difficult for investors to obtain information [31]. Controlling shareholders with equity pledges are more likely to manage real earnings by manipulating assets measured by fair value. Fair value measurement is used for upward real earnings management, which can adjust earnings on the one hand and reduce the risk of control transfer on the other.

5.2. The Influence of the Risk of Control Transfer on the Adjustment of Fair Value Measurement. When overconfident major shareholders are pledged, the risk of stock price collapse reflects the downward trend of individual stock price, which can reflect the risk of control transfer to a certain extent. This article draws on the practices of Hutton et al., [32], Kim et al. [33], and Xu et al. [34] to measure the risk of stock price collapse of listed companies. First, the weekly return data of stock $i$ are used to perform the following regression every year:

$$
\begin{aligned}
R_{i t}= & \alpha_{i}+\beta_{1} R_{m t-2}+\beta_{2} R_{m t-1}+\beta_{3} R_{m t}+\beta_{4} R_{m t+1} \\
& +\beta_{5} R_{m t+2}+\varepsilon_{i t} .
\end{aligned}
$$

$R_{i t}$ is the return rate of stock $i$ considering cash dividend reinvestment in week $t, R_{m t}$ is the average return rate weighted by the circulating market value of all stocks of $A$ shares in week $t$, the company-specific income of stock $i$ in week $t$ is $W_{i t}=\operatorname{Ln}\left(1+\varepsilon_{i t}\right)$, and $\varepsilon_{i t}$ is the residual of regression equation (4). Secondly, based on $\mathrm{W}_{\mathrm{it}}$, the following variable is constructed:

$$
\operatorname{NCSKEW}_{i t}=\frac{-\left[n(n-1)^{3 / 2} \sum W_{i t}^{3}\right]}{\left[(n-1)(n-2)\left(\sum W_{i t}^{2}\right)^{3 / 2}\right]} .
$$

In model (5), NCSKEW is the negative return skewness coefficient. $n$ is the number of trading weeks for stock $i$ each year. The larger the value of NCSKEW, the more negative the skewness coefficient and the greater the risk of crash. The risk of higher than the average stock price crash is $\mathrm{CRASH}=1$, and the risk of lower than the average is $\mathrm{CRASH}=0$. Descriptive statistics are in Table 7 .

As shown in Table 8 , the coefficients of Afv $\times$ Con in columns (1) and (2) are 0.407 and -0.293 , respectively, and the former is significantly positive at the $1 \%$ level, and the empirical $P$ value between groups is 0.015 , which is 
TABLE 7: Descriptive statistics of CRASH.

\begin{tabular}{lccccc}
\hline Variable & Mean & sd & min & p50 & max \\
\hline CRASH & 0.080 & 0.280 & 0 & 0 & 1 \\
\hline
\end{tabular}

TABLE 8: The impact of stock price collapse risk on the adjustment of fair value measurement.

\begin{tabular}{|c|c|c|c|c|}
\hline $\begin{array}{l}\text { Regression } \\
\text { model } \\
\text { Crash risk }\end{array}$ & $\begin{array}{c}(1) \\
\text { Psg } \\
\text { CRASH }=0\end{array}$ & $\begin{array}{c}(2) \\
\text { Psg } \\
\text { CRASH }=1\end{array}$ & $\begin{array}{c}(3) \\
\text { Ratio } \\
\text { CRASH }=0\end{array}$ & $\begin{array}{c}(4) \\
\text { Ratio } \\
\text { CRASH = 1 }\end{array}$ \\
\hline Con & $\begin{array}{l}-0.104 \\
(0.425)\end{array}$ & $\begin{array}{c}0.519 \\
(0.248)\end{array}$ & $\begin{array}{c}-2.952^{*} \\
(0.090)\end{array}$ & $\begin{array}{c}2.270 \\
(0.660)\end{array}$ \\
\hline $\mathrm{Afv} \times \mathrm{Con}$ & $\begin{array}{c}0.407^{* * *} \\
(0.008)\end{array}$ & $\begin{array}{l}-0.293 \\
(0.562)\end{array}$ & $\begin{array}{c}7.297^{* * *} \\
(0.001)\end{array}$ & $\begin{array}{c}2.245 \\
(0.709)\end{array}$ \\
\hline Afv & $\begin{array}{l}-0.065 \\
(0.574)\end{array}$ & $\begin{array}{c}0.342 \\
(0.387)\end{array}$ & $\begin{array}{c}-3.717^{* *} \\
(0.031)\end{array}$ & $\begin{array}{l}5.865 \\
(0.212)\end{array}$ \\
\hline$L 1$ size & $\begin{array}{c}0.020 \\
(0.456)\end{array}$ & $\begin{array}{c}-0.215^{* * *} \\
(0.010)\end{array}$ & $\begin{array}{c}0.878^{* * * *} \\
(0.006)\end{array}$ & $\begin{array}{c}-1.896^{* *} \\
(0.012)\end{array}$ \\
\hline Dual & $\begin{array}{l}0.255^{* * *} \\
(\leq 0.001)\end{array}$ & $\begin{array}{l}-0.144 \\
(0.491)\end{array}$ & $\begin{array}{l}3.611 \\
(\leq 0.0\end{array}$ & $\begin{array}{l}-1.910 \\
(0.426)\end{array}$ \\
\hline Prof & $\begin{array}{l}-0.052^{* * *} \\
(\leq 0.001)\end{array}$ & $\begin{array}{c}-0.069^{* *} \\
(0.044)\end{array}$ & $\begin{array}{c}-0.508^{* * *} \\
(\leq 0.001)\end{array}$ & $\begin{array}{c}-0.517^{* * * *} \\
(0.001)\end{array}$ \\
\hline Growth & $\begin{array}{c}-1.619^{* * *} \\
(\leq 0.001)\end{array}$ & $\begin{array}{c}-1.593^{* * *} \\
(\leq 0.001)\end{array}$ & $\begin{array}{c}-16.600^{* * *} \\
(\leq 0.001)\end{array}$ & $\begin{array}{c}-13.670^{* * *} \\
(\leq 0.001)\end{array}$ \\
\hline Ppe & $\begin{array}{l}0.461^{*} \\
(0.056)\end{array}$ & $\begin{array}{c}0.183 \\
(0.812)\end{array}$ & $\begin{array}{c}3.468 \\
(0.270)\end{array}$ & $\begin{array}{l}-0.825 \\
(0.923)\end{array}$ \\
\hline Dual & $\begin{array}{c}0.217^{* * * *} \\
(0.001)\end{array}$ & $\begin{array}{l}-0.104 \\
(0.609)\end{array}$ & $\begin{array}{c}3.163^{* * *} \\
(0.003)\end{array}$ & $\begin{array}{l}1.045 \\
(0.707)\end{array}$ \\
\hline Lev & $\begin{array}{l}0.778^{* * * *} \\
(\leq 0.001)\end{array}$ & $\begin{array}{l}1.256^{* *} \\
(0.019)\end{array}$ & $\begin{array}{c}14.630^{* * *} \\
(\leq 0.001)\end{array}$ & $\begin{array}{c}18.310^{* * * *} \\
(0.006)\end{array}$ \\
\hline $\begin{array}{l}\text { Year/Ind } \\
\text { Empirical } P \\
\text { value }\end{array}$ & \multicolumn{2}{|c|}{0.015} & \multicolumn{2}{|c|}{0.127} \\
\hline $\begin{array}{l}N \\
\text { Adj. } R^{2}\end{array}$ & $\begin{array}{l}5585 \\
0.108\end{array}$ & $\begin{array}{c}646 \\
0.104\end{array}$ & $\begin{array}{l}5604 \\
0.079\end{array}$ & $\begin{array}{c}671 \\
0.070\end{array}$ \\
\hline
\end{tabular}

Note. ${ }^{* * *},{ }^{* *}$, and ${ }^{*}$ represent significance levels of $1 \%, 5 \%$, and $10 \%$, respectively.

significant. It shows that in a company with a lower risk of stock price collapse, the adjustment effect of fair value measurement is easier to increase the probability of overconfident major shareholders to pledge equity. The coefficients of Afv $\times$ Con in columns (3) to (4) are, respectively, 7.297 and 2.245 . Although the former is significantly positive at the $1 \%$ level and the latter is not significant, the empirical $P$ value between groups is 0.127 . It shows that the level of stock price collapse risk has no significant difference in the impact of fair value measurement on the proportion of equity pledge. It shows that when the stock price is stable, the adjustment effect of fair value measurement is relatively more significant.

5.3. The Influence of the External Supervision on the Adjustment of Fair Value Measurement. This article also examines the influence of external supervision on the adjustment of fair value measurement, including audit quality that measured by whether to choose the Big Four accounting firms (Big4) or the level of audit costs (Cost), and analyst attention
TABle 9: Descriptive statistics of Maa, Big4, and Mcost.

\begin{tabular}{lccccc}
\hline Variables & Mean & sd & min & p50 & Max \\
\hline Maa & 0.500 & 0.500 & 0 & 1 & 1 \\
Big4 & 0.060 & 0.240 & 0 & 0 & 1 \\
Mcost & 0.260 & 0.440 & 0 & 0 & 1 \\
\hline
\end{tabular}

TABLE 10: The impact of external supervision on the adjustment of fair value measurement.

\begin{tabular}{|c|c|c|c|c|}
\hline $\begin{array}{l}\text { Panel A } \\
\text { Models } \\
\text { Variables } \\
\end{array}$ & $\begin{array}{c}(1) \\
\text { Maa =0 } \\
\text { Psg }\end{array}$ & $\begin{array}{c}(2) \\
\mathrm{Maa}=1 \\
\text { Psg }\end{array}$ & $\begin{array}{c}(3) \\
\text { Maa =0 } \\
\text { Ratio }\end{array}$ & $\begin{array}{c}(4) \\
\text { Maa = } 1 \\
\text { Ratio }\end{array}$ \\
\hline Con & $\begin{array}{l}-0.009 \\
(0.958)\end{array}$ & $\begin{array}{l}-0.096 \\
(0.578)\end{array}$ & $\begin{array}{l}-2.362 \\
(0.307)\end{array}$ & $\begin{array}{l}-3.609 \\
(0.123)\end{array}$ \\
\hline Afv $\times$ Con & $\begin{array}{c}0.489^{* *} \\
(0.015)\end{array}$ & $\begin{array}{c}0.249 \\
(0.209)\end{array}$ & $\begin{array}{c}8.645^{* * *} \\
(0.004)\end{array}$ & $\begin{array}{c}6.502^{* *} \\
(0.016)\end{array}$ \\
\hline Afv & $\begin{array}{l}-0.055 \\
(0.703) \\
\end{array}$ & $\begin{array}{l}-0.102 \\
(0.508) \\
\end{array}$ & $\begin{array}{l}-0.762 \\
(0.725) \\
\end{array}$ & $\begin{array}{c}-6.337^{* * *} \\
(0.005) \\
\end{array}$ \\
\hline Empirical $P$ value & \multicolumn{2}{|c|}{0.207} & \multicolumn{2}{|c|}{0.298} \\
\hline $\begin{array}{l}N \\
\text { Adj. } R^{2}\end{array}$ & $\begin{array}{l}3265 \\
0.101\end{array}$ & $\begin{array}{l}3457 \\
0.116\end{array}$ & $\begin{array}{l}3272 \\
0.076\end{array}$ & $\begin{array}{c}3471 \\
0.073\end{array}$ \\
\hline $\begin{array}{l}\text { Panel B } \\
\text { Variables }\end{array}$ & $\begin{array}{c}\text { Big4 }=0 \\
\text { Psg }\end{array}$ & $\begin{array}{c}\text { Big4=1 } \\
\text { Psg }\end{array}$ & $\begin{array}{c}\text { Big4 }=0 \\
\text { Ratio }\end{array}$ & $\begin{array}{c}\text { Big4 = } 1 \\
\text { Ratio }\end{array}$ \\
\hline Con & $\begin{array}{l}-0.054 \\
(0.657)\end{array}$ & $\begin{array}{c}1.011 \\
(0.509)\end{array}$ & $\begin{array}{c}-3.099^{*} \\
(0.063)\end{array}$ & $\begin{array}{c}2.353 \\
(0.680)\end{array}$ \\
\hline $\mathrm{Afv} \times \mathrm{Con}$ & $\begin{array}{l}0.295^{* *} \\
(0.037)\end{array}$ & $\begin{array}{c}0.478 \\
(0.758)\end{array}$ & $\begin{array}{c}6.927^{* * *} \\
(0.001)\end{array}$ & $\begin{array}{c}6.839 \\
(0.361)\end{array}$ \\
\hline Afv & $\begin{array}{l}-0.039 \\
(0.717)\end{array}$ & $\begin{array}{l}-0.054 \\
(0.953)\end{array}$ & $\begin{array}{c}-2.950^{*} \\
(0.071)\end{array}$ & $\begin{array}{l}-3.500 \\
(0.136)\end{array}$ \\
\hline Empirical $P$ value & \multicolumn{2}{|c|}{0.252} & \multicolumn{2}{|c|}{0.486} \\
\hline $\begin{array}{l}N \\
\text { Adj. } R^{2}\end{array}$ & $\begin{array}{c}6411 \\
0.097\end{array}$ & $\begin{array}{c}278 \\
0.281\end{array}$ & $\begin{array}{l}6428 \\
0.070\end{array}$ & $\begin{array}{c}315 \\
0.084\end{array}$ \\
\hline $\begin{array}{l}\text { Panel C } \\
\text { Variables }\end{array}$ & $\begin{array}{c}\text { Mcost }=0 \\
\text { Psg }\end{array}$ & $\begin{array}{c}\text { Mcost }=1 \\
\text { Psg }\end{array}$ & $\begin{array}{c}\text { Mcost }=0 \\
\text { Ratio }\end{array}$ & $\begin{array}{c}\text { Mcost }=1 \\
\text { Ratio }\end{array}$ \\
\hline Con & $\begin{array}{l}-0.077 \\
(0.551)\end{array}$ & $\begin{array}{c}0.241 \\
(0.502)\end{array}$ & $\begin{array}{c}-3.723^{* *} \\
(0.037)\end{array}$ & $\begin{array}{c}2.456 \\
(0.540)\end{array}$ \\
\hline $\mathrm{Afv} \times \mathrm{Con}$ & $\begin{array}{l}0.390^{* *} \\
(0.011)\end{array}$ & $\begin{array}{l}-0.056 \\
(0.886)\end{array}$ & $\begin{array}{l}7.827^{* * *} \\
(\leq 0.001)\end{array}$ & $\begin{array}{c}0.900 \\
(0.841)\end{array}$ \\
\hline Afv & $\begin{array}{l}-0.047 \\
(0.691)\end{array}$ & $\begin{array}{c}0.167 \\
(0.505)\end{array}$ & $\begin{array}{l}-3.008 \\
(0.115)\end{array}$ & $\begin{array}{l}-1.656 \\
(0.515)\end{array}$ \\
\hline Empirical $P$ value & \multicolumn{2}{|c|}{0.065} & \multicolumn{2}{|c|}{0.041} \\
\hline Controls & Yes & Yes & Yes & Yes \\
\hline Year/Ind & Yes & Yes & Yes & Yes \\
\hline$N$ & 5032 & 1684 & 5048 & 1695 \\
\hline Adj. $R^{2}$ & 0.088 & 0.163 & 0.059 & 0.127 \\
\hline
\end{tabular}

Note. ${ }^{* * *},{ }^{* *}$, and ${ }^{*}$ represent significance levels of $1 \%, 5 \%$, and $10 \%$, respectively. Each set of regression controls the control variables, year, and industry, which are abbreviated due to space reasons.

(AA). We set two variable Mcost and Maa to represent the grouping dummy variables of audit fees (Cost) and analyst attention (AA). If the data is higher than the average of audit fees (Cost) or analyst attention (AA), then Mcost $=1$ or $\mathrm{Maa}=1$; otherwise, it is 0 . The test is grouped according to $\operatorname{Big} 4=1$ or Big $4=0, M \operatorname{cost}=1$ or Mcost $=0$, and $\mathrm{Maa}=1$ or Maa $=0$. Table 9 shows the descriptive statistics.

As shown in Table 10, the $P$ value of the difference between the groups in Panel A and Panel B is not significant, indicating that analyst attention and whether the Big Four have no influence on the moderating effect of fair value 
measurement. The $P$ values of the difference between the groups in Panel C are 0.065 and 0.041, respectively, and the multiplier is not significant in the higher audit fee, indicating that higher audit fees can help restrain the adjustment effect of fair value measurement, and the probability and ratio of equity pledges by overconfident major shareholders will decrease.

When a company is affected by the economic environment, the adjustment effect of fair value measurement is significantly reduced, and the level of corporate governance within the company will also inhibit the adjustment effect of fair value measurement to a certain extent. Through the above inspection, it can be shown that good internal corporate governance and external supervision can help reduce the regulatory role of fair value measurement $[35,36]$.

\section{Conclusion}

Fair value measurement has been used in China for more than ten years, and it has become more and more perfect with the continuous adjustment of standards. The company's major shareholders have also turned from their cautious attitude during the financial crisis to skillfully using fair value measurement to manipulate earnings. This paper takes the companies whose major shareholders increase their holdings and the return on net assets of the following year declines sequentially as a sample of major shareholders' overconfidence to test whether fair value measurement has a moderating effect on overconfident major shareholders' radical financing decisions evidence. Studies have found that fair value measurement will increase the probability of overconfident major shareholders' equity pledge and increase the ratio of equity pledge. Further inspection found that if the level of accrued earnings management is higher, fair value measurement has a higher regulating effect; in an environment with a lower risk of stock price collapse, fair value measurement has a significant effect on the probability of overconfident major shareholders' equity pledge. Among the methods of external supervision, higher audit fees are more effective. According to the regression results, fair value measurement has a greater impact when the environment is relatively stable. The improvement of corporate governance can inhibit the effect of fair value measurement on financing decision-making, but the effect of external supervision is poor.

As far as enterprises are concerned, the different accounting measurement attributes will cause decision makers to require more subjective judgments when financing. Fair value measurement will lead to radical financing by major shareholders, which will undoubtedly increase the risk of the company's operations, but auditors and analysts have limited restraint. It is recommended that the regulatory authorities of enterprises should pay attention to the issues of earnings management and market fluctuations and may choose a higher audit fee. In addition, it is recommended to refine the fair value issues in the audit standards to improve audit effectiveness.

These findings reveal the characteristics of overconfident major shareholders' financing decision-making behaviors of companies that adopt fair value measurement, thereby expanding the relevant theories of corporate governance and providing reference for seeking relevant paths to optimize corporate governance from the perspective of internal governance and external supervision.

\section{Data Availability}

The data used to support the findings of this study are included within the article.

\section{Conflicts of Interest}

The authors declare that they have no conflicts of interest regarding the publication of this paper.

\section{Acknowledgments}

This study was funded by the Anhui Provincial Department of Education Quality Engineering Project (Planning Textbook), Economic Benefit Audit, (no. 2017ghjc119), Teaching Research Project of Anhui University of Finance and Economics (no. cxjhjyzdi1907), and Major Project of the Key Research Base of Humanities and Social Sciences of the Ministry of Education "Accounting Measurement Model, Report Model, and Enterprise Comprehensive Report" (no. 16JJD790035).

\section{References}

[1] D. Langevoort, "Organized illusions: a behavioral theory of why corporations mislead stock market investors (and cause other social harms)," University of Pennsylvania Law Review, vol. 146, no. 1, pp. 101-172, 1998.

[2] M. L. Cheng, Research on the Relationship between Overconfidence of the Biggest Shareholder and the Pledge of Shareholders, Harbin Institute of Technology, Harbin, China, 2017.

[3] S. L. Wang, S. H. Li, and X. T. Xu, "Fair value measurement hierarchy, auditor industry expertise and earnings management," Auditing Research, vol. 5, pp. 86-95, 2020.

[4] D. Tadeusz and P. Z. Jadwiga, "Does the mark-to-model fair value measure make assets impairment noisy?: a literature review," Sustainability, vol. 12, p. 1504, 2020.

[5] S. H. Penman, "Financial reporting quality: is fair value a plus or a minus?" Accounting and Business Research, vol. 37, no. 1, pp. 33-44, 2007.

[6] Z. C. Wu, S. D. Luo, and W. Wang, "The research on value relevance and earnings management of securities gains and losses," Accounting Research, vol. 6, pp. 42-49+97, 2009.

[7] X. He, T. J. Wong, and D. Young, "Challenges for implementation of fair value accounting in emerging markets: evidence from China," Contemporary Accounting Research, vol. 29, no. 2, pp. 538-562, 2012.

[8] Y. L. Liao, "Equity pledge, audit agency selection and real earnings management," Productivity Research, vol. 12, pp. 135-139, 2020.

[9] K. Liao, C. Y. Cui, and D. R. Xie, "Controlling shareholders' share pledging and dividends policy choice of listed companies," Journal of Financial Research, vol. 4, pp. 172-189, 2018. 
[10] P. L. He, L. Z. Xin, Z. Y. Pan et al., "Motivation of stock dividend transfer behavior of listed companies evidence based on perspective of equity pledge financing," Accounting Research, vol. 3, pp. 57-63, 2018.

[11] D. R. Xie, D. J. Zheng, and C. Y. Cui, "Is controlling shareholder's share pledge a potential "mine"?" Management World, vol. 27, no. 5, pp. 128-14088, 2016.

[12] X. Y. Wang, C. Y. Ouyang, and Z. Y. Shi, "Controlling shareholder's shares pledge, the risk of losing control rights and tax avoidance," Economic Research Journal, vol. 53, no. 1, pp. 138-152, 2018.

[13] J. Z. Fang, "An empirical analysis of the equity pledge of China's A shares listed companies," Financial Market Research, vol. 69, no. 2, pp. 122-135, 2018.

[14] Y. Lin, L. B. Wei, and W. Li, "Research on controlling shareholder's equity Pledge,Equity nature and corporate performance," Commercial Research, vol. 49, no. 2, pp. 50-56, 2018.

[15] M. Hanlon and S. Heitzman, "A review of tax research," Journal of Accounting and Economics, vol. 50, no. 2-3, pp. 127-178, 2010.

[16] M. A. Desai and D. Dharmapala, "Corporate tax avoidance and firm value," Review of Economics and Statistics, vol. 91, no. 3, pp. 537-546, 2009.

[17] J.-B. Kim, Y. Li, and L. Zhang, "Corporate tax avoidance and stock price crash risk: firm-level analysis," Journal of Financial Economics, vol. 100, no. 3, pp. 639-662, 2011.

[18] M. Mironov, "Taxes, theft, and firm performance," The Journal of Finance, vol. 68, no. 4, pp. 1441-1472, 2013.

[19] J. Z. Sun, "Research on tunneling behavior under equity pledge of controlling shareholder," Finance and Accounting for International Commerce, vol. 3, pp. 90-96, 2018.

[20] Z. Y. Chen, C. Q. Li, and Z. H. Huang, "Equity pledge, equity incentives and capital appropriation of major shareholders," South China Finance, vol. 3, pp. 23-32, 2018.

[21] L. D. Hodder, P. E. Hopkins, and J. M. Wahlen, "Risk-relevance of fair-value income measures for commercial banks," The Accounting Review, vol. 81, no. 2, pp. 337-375, 2006.

[22] M. E. Barth, W. H. Beaver, and W. R. Landsman, "Relative valuation roles of equity book value and net income as a function of financial health," Journal of Accounting and Economics, vol. 25, no. 1, pp. 1-34, 1998.

[23] K. Nelson, "Fair value accounting for commercial banks an empirical analysis of SFAS No.107," The Accounting Review, vol. 71, no. 2, pp. 161-182, 1996.

[24] E. A. Eccher, K. Ramesh, and S. R. Thiagarajan, "Fair value disclosures by bank holding companies," Journal of Accounting and Economics, vol. 22, no. 1-3, pp. 79-117, 1996.

[25] F. Wen and W. H. Cu, "The overconfidence behavior of major shareholders and the effectiveness of corporate governance: empirical test based on the increase of holdings by major shareholders," Securities Market Herald, vol. 23, no. 12, pp. 11-16, 2011.

[26] Z. F. Li, H. L. Li, and Y. J. Lian, "The market reaction to the presentation of the changes in the fair value: evidence from Chinese listed firms," Accounting Research, vol. 10, pp. 13-96, 2013.

[27] M. E. Barth and G. Clinch, "Revalued financial, tangible, and intangible assets: associations with share prices and nonmarket-based value estimates," Journal of Accounting Research, vol. 36, pp. 199-233, 1998.

[28] D. Aboody, M. E. Barth, and R. Kasznik, "Revaluations of fixed assets and future firm performance: evidence from the
UK," Journal of Accounting and Economics, vol. 26, no. 1-3, pp. 149-178, 1999.

[29] J. Q. Lu, "An empirical study on earnings management of China's loss listed companies," Accounting Research, vol. 9, pp. 25-35, 1999.

[30] J. Sun, B. Q. Wang, F. Cao et al., "Does company strategy affect earnings management?" Management World, vol. 270, no. 3, pp. 160-169, 2016.

[31] L. J. Yao and D. L. Xia, "Can banks in China see through firms' earnings quality?” Auditing Research, vol. 3, pp. 91-96, 2009.

[32] A. P. Hutton, A. J. Marcus, and H. Tehranian, "Opaque financial reports, R2, and crash risk," Journal of Financial Economics, vol. 94, no. 1, pp. 67-86, 2009.

[33] N. X. Xu, X. Y. Jiang, Z. H. Yi et al., "Conflicts of Interest,Analyst optimism and stock price crash risk," Economic Research Journal, vol. 47, no. 7, pp. 127-140, 2012.

[34] R. Xie, W.-B. Li, M. C. Lin et al., "Research on the human rights and cultural protection of environmentally displaced persons under rising sea levels," Complexity, vol. 2021, Article ID 6627637, 11 pages, 2021.

[35] J. M. Zhu, Y. Chen, and S. Zhang, "Analysis of the impact of climate change on national vulnerability based on fuzzy comprehensive evaluation," Discrete Dynamics in Nature and Society, vol. 2020, Article ID 3527540, 10 pages, 2020.

[36] J. M. Zhu, L. Wang, and J. B. Liu, "Eradication of Ebola based on dynamic programming," Computational and Mathematical Methods in Medicine, vol. 2016, Article ID 1580917, 9 pages, 2016. 